\title{
AVP-013 腹腔鏡下膀胼部分切除術
}

\section{関西医科大学泌尿器科学}

木下 秀文, 安田 鐘樹, 地崎 竜介, 井上 貴昭, 川喜多 繁誠, 大口 尚基, 河 源, 六車 光英, 松田 公志 【背景】膀胱部分切除術が必要となる腫崵性病変は稀ではあるが存在する。現在まで，これらに対する手術は開放手術で行われてきた が，より低侵襲の手術として腹胿鏡下での手術法の確立が望まれる.【対象】平滑筋腫 (術前生検では border line malignancy) と层膜 管癌に対して, 腹胿鏡下膀胱部分切除術および骨盤部リンパ節隔清術を行った。【方法】ポートは 4 本，カメラポート，右下腹部 1 本，左下腹部 1 本，恥骨腈間 1 本とした１）平滑筋腫は膀胱左壁に存在したため，後腹膜アプローチとした，腹膜は腫嗙部分を覆って いなかったため，膀胱から腹膜を剥離して切除㧍よび縫合のためのマージンを十分に碓保した．膀胼鏡で確認しながら，腫場から十分に

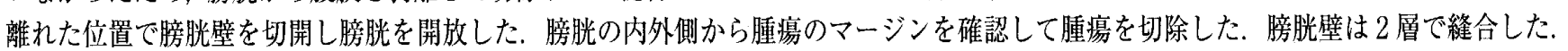
2) 尿膜管癌に対しては，経腹膜的にアプローチし尿膜管および腹膜を en-bloc に切除した. open lapalotomy でカメラポートを置く際に 尿膜管と側臍索を確認し，臍の部分で結禁した，用手的に腹膜および尿膜管を腹壁から剥離し，側胎索の外側で腹膜を切開した，断端は

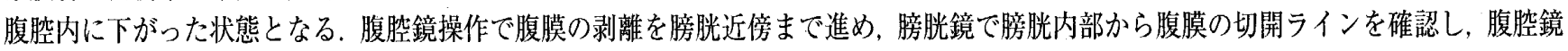
操作をモニタリングした. 膀胱壁は粘膜を残して切開し，切除ラインを被薄化した後. End-GIA で切除した。 この際も膀椫鏡で腫場から のマージンを確認した，膀胱の切除体外への取り出し後， stapler metalsを切除し膀胱を開放した．膀胱壁を2層で縫合した．1）2）と もに，膀肤縫合後，骨盤部リンパ節隔清術を行った，隔清範囲は，1）では閉鎖リンパ節を中心とし，2）では閉鎖および内腸骨，外腸骨， 総腸骨の遠位とした。【成績】手術時間は1）6 時間 30 分（標本取出しまでは 3 時間 30 分）2） 9 時間（同 2 時間 50 分）であり，出血量 は 130-150mlであつた，手術時間はこれらの手術の膀腅の縫合およびリンパ節隔清が，シニアレジデントの教育プログラムに含まれた ため，長時間となった，術後は疼痛も軽度であった，病理組織はともに十分なマージンを有し完全に切除されていた．【結論】腹胫鏡下 手術の技術の進歩に伴いその適応は拡大されているが，膀肤部分切除術も非常に良い適応となると考えられた，開放手術と同様に難易度 は腫瘍病変の位置によると考えられ，頂部に近いものほど容易である。膀胱部分切除術の適応となる疾患自体が限られるが, 例えば屎膜 管癌のような尿膜管と腹膜の合併切除が必要な症例でも en-bloc の切除が可能である. 腫瘍細胞を含む尿の污染も end-GIの使用により 防止できる，腹腔鏡下膀胱部分切除術は，適応疾患に対して積極的に選択されるべき術式であると考える.

\section{AVP-014 高度な前部尿道狭窄に対する新しい尿道形成術：有茎包皮内板を用いた腹側被覆型遠位尿道形 成術と遊離口腔粘膜を用いた背倒被覆型近位尿道形成術の併用}

\section{山梨大学大学院医学工学総合研究部泌尿器科学1), 山梨大学大学院医学工学総合研究部耳鼻咽喉科学 ${ }^{22}$}

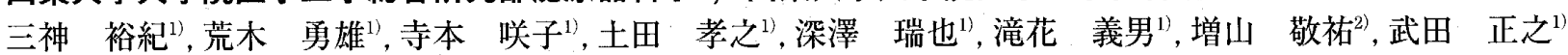
長い複雑な前部尿道狭窄に対しては, 包皮内板の有茎フラップを用いた腹側被覆型尿道形成術と, 口腔粘膜遊離グ ラフトを用いた背側被覆型尿道形成術が最も新しい方法であるが，それぞれ欠点を有する。 そこで，長い複雑な 前部尿道狭窄に対して, 包皮内板の有茎フラップを用いた腹側被覆型尿道形成術と, 口腔粘膜遊離グラフトを用い た背側被覆型尿道形成術を併用し, 良好な結果を得たので報告する。症例：35歳男性, 内視鏡手術後に発生した振 子部から球部にわたる約 $8 \mathrm{~cm}$ の高度な尿道狭窄を有していた。最大尿流率は，1.5ml/秒であった，術式：まず会 陰切開により，尿道海綿体を十分に遠位まで剥離した。陰茎皮虐に冠状溝直下で全周性の皮膚切開を㧍き, 陰茎 根部まで陰茎皮虐を剥離した。約 $1 \mathrm{~cm}$ 幅の円周状の有茎皮膚フラップを作成し, これを陰荠腹側に移行させ, さ らに会陰部創へ移行させた。外尿道口から挿入した金属ブジーをガイドに振子部尿道狭窄の腹側を縦切開した. $22 \mathrm{~F}$ フォーレカテーテルを留置して膀胱瘦を造設した後, 陰茎包皮の有荎フラップを用いて腹側被覆型振り子部尿 道形成術を行った。次いで, 尿道海綿体を 180 度回転させてから球部尿道を背側で切開した. 口腔粘膜を採取 し，これを楕円状にトリミングしてから，陰茎海綿体腹側の白膜に縫合固定した。球部尿道切開縁と既に陰荎海 綿体に縫合固定した対応する口䏕粘膜パッチとを縫合し, 背側被覆型球部尿道形成術を行った. ドレーンを会陰 部に留置して会陰部創を 3 層以上に閉鎖し, 陰茎包皮切開部を閉鎖した. フォーレーカテーテルは 3 週間留した. 結果 : 術後 2 ケ月目の尿流測定では, 最大尿流率は, $27.95 \mathrm{ml} /$ 秒であった。尿道造影, 尿道内視鏡検査でも, 正常 な太さの尿道を認めた. 結論 : 長い複雑な前部尿道狭窄に対して, 包皮内板の有茎フラップを用いた腹側被覆型尿 道形成術と口腔粘膜遊離グラフトを用いた背側被覆型尿道形成術の併用は, 極めて有用な術式である. 